\title{
Cannabinoids Activate an Inwardly Rectifying Potassium Conductance and Inhibit Q-Type Calcium Currents in AtT20 Cells Transfected with Rat Brain Cannabinoid Receptor
}

\author{
K. Mackie, ${ }^{1}$ Y. Lai, ${ }^{2}$ R. Westenbroek, ${ }^{3}$ and R. Mitchell ${ }^{2}$ \\ 'Departments of Anesthesiology and Physiology and Biophysics, University of Washington, Seattle, Washington \\ 98195, '2Panlabs, Bothell, Washington 98011-8805, and ${ }^{3}$ Department of Pharmacology, University of Washington, \\ Seattle, Washington 98195
}

Rat brain cannabinoid receptor (CB-1) was stably transfected into the murine tumor line AtT-20 to study its coupling to inwardly rectifying potassium currents $\left(K_{\mathrm{ir}}\right)$ and high voltage-activated calcium currents $\left(I_{\mathrm{Ca}}\right)$. In cells expressing CB-1 ("A-2"' cells), cannabinoid agonist potently and stereospecifically activated $K_{i r}$ via a pertussis toxinsensitive $G$ protein. $I_{C a}$ in A-2 cells was sensitive to dihydropyridines and $\omega \mathrm{CTX}$ MVIIC, less so to $\omega \mathrm{CgTX}$ GVIA and insensitive to wAga IVa. In CB-1-expressing cells, cannabinoid agonist inhibited only the $\omega C T X$ MVIIC-sensitive component of $I_{\mathrm{Ca}}$. Inhibition of Q-type $I_{\mathrm{Ca}}$ was voltage dependent and PTX sensitive, thus similar in character to the well-studied modulation of $\mathrm{N}$-type $I_{\mathrm{Ca}}$. An endogenous cannabinoid, anandamide, activated $K_{\mathrm{lr}}$ and inhibited $I_{\mathrm{ca}}$ as efficaciously as potent cannabinoid agonist. Immunocytochemical studies with antibodies specific for class A, B, C, $D$, and $E$ voltage-dependent calcium channel $\alpha_{1}$ subunits revealed that AtT-20 cells express each of these major classes of $\alpha_{1}$ subunit.

[Key words: cannabinoid, calcium current, G protein, potassium current, AtT-20, anandamide]

Cannabinoids, the primary psychoactive constituents of marijuana, have profound effects on mood, perception, and memory. Most of these effects appear to be mediated via the brain (CB1) cannabinoid receptor (Pertwee, 1993). This receptor is a member of the $G$ protein-coupled receptor superfamily (Matsuda et al., 1990) and previously has been shown to couple in an inhibitory fashion to adenylyl cyclase (Howlett, 1985) and $\mathrm{N}$-type calcium channels (Caulfield and Brown, 1992; Mackie and Hille, 1992). In neurons and other excitable cells, several $G$ protein coupled receptors also activate inwardly rectifying potassium channels via a pertussis toxin sensitive $G$ protein (North, 1989; Kubo et al., 1993). These channels often contribute to

\footnotetext{
Received Mar. 24, 1995; revised May 16, 1995; accepted May 19, 1995.

We thank L. Matsuda for providing the CB-1 receptor cDNA; M. Watson, S. Bounds, S. Brown, D. Anderson, and L. Miller for technical help; B. Hille for helpful discussions and facilities; W. Catterall, J. Harrington, B. Nair, and M. Shapiro for reading the manuscript; W. Devane and R. Mechoulam for providing anandamide; Neurex for providing SNX 230; and Sterling Winthrop for providing WIN 55,212-2 and WIN 55,212-3. This work was supported by Foundation for Anesthesia Education and Research, the Keck Foundation, a McKnight Neuroscience Research Award, and the NIH Grants NS01588 and NS08174.

Correspondence should be addressed to Ken Mackie, Department of Anesthesiology, RN-10, University of Washington, Seattle, WA 98195.

Copyright (C) 1995 Society for Neuroscience $0270-6474 / 95 / 156552-10 \$ 05.00 / 0$
}

setting the resting membrane potential and play a major rolc in determining neuronal excitability. In addition to N-type calcium channels, some neuronal $G$ protein-coupled receptors also appear to be able to modulate P-type $I_{\mathrm{Ca}}$ and other, less well characterized, voltage-dependent calcium channels (Mintz and Bean, 1993). We asked the question if the same was true for CB-1 receptor. Lacking a neuronal preparation expressing the appropriate ion channels and cannabinoid receptor, and desiring to establish a system for investigating cannabinoid receptor-effector coupling, we transfected the mouse tumor cell line, AtT20, with rat CB-1 receptor. This cell line was chosen as it expresses an inwardly rectifying potassium current that is activated by somatostatin (Dousmanis and Pennefather, 1992; Pennefather et al., 1988) and $\mathrm{m}_{4}$ muscarinic receptors (Jones, 1992). In addition it expresses high voltage-activated calcium currents that are inhibited by $\mathrm{G}$ protein-coupled receptors (Luini et al., 1986; Surprenant et al., 1992). AtT-20 cells secrete $\beta$-endorphin and ACTH and have served as a useful model for studying neuropeptide synthesis, transport and release (Burgess and Kelly, 1987; Matsuuchi and Kelly, 1991). Although they are often assumed to be closely related to pituitary corticotrophs, strong evidence has been presented that these cells have many enzymatic and structural features more in common to neuropeptide secreting neurons (Tooze et al., 1989). Thus, they may be a more appropriate model to study neuronal processes than previously appreciated. By detcrmining how cannabinoid receptors couple to ion channels, we hope to increase our understanding of the mechanisms underlying the behavioral actions of cannabinoids and the endogenous ligands for this receptor.

The indentification and classification of voltage-dependent calcium channels is still evolving (Birnbaumer et al., 1994). In the rat brain, multiple isoforms of the principal $\alpha_{1}$ subunit of voltage-dependent calcium channels have been identified using molecular cloning techniques and have been designated class $\mathrm{A}$, B, C, D, and E (Snutch et al., 1990; Snutch and Reiner, 1992; Birnbaumer et al., 1994; Soong et al., 1994). The rat brain class $\mathrm{C}$ and $\mathrm{D}$ genes encode L-type calcium channel $\alpha_{1}$ subunits $\left(\alpha_{1 \mathrm{C}}\right.$ and $\alpha_{1 \mathrm{D}}$ ) which have a high affinity for dihydropyridine calcium channel antagonists and are approximately $75 \%$ identical in amino acid sequence with rabbit skeletal muscle calcium channels and L-type calcium channels from other tissues (Snutch et al., 1990; Hui et al., 1991; Chin et al., 1992; Dubel et al., 1992; Seino et al., 1992; Williams et al., 1992; Tomlinson et al., 1993). The rat brain class B gene encodes $\mathrm{N}$-type calcium channel $\alpha_{1}$ subunits with high affinity for $\omega$-conotoxin-GVIA (Dubel et al., 
1992; Williams et al., 1992). The class A gene encodes $\alpha_{1}$ subunits which form a high-voltage-activated calcium channel with novel physiological and pharmacological properties and is highly expressed in the ccrcbcllum (Mori ct al., 1991; Starr ct al., 1991; Sather et al., 1993). The class A channels are insensitive to dihydropyridines and $\omega$-conotoxin-GVIA, weakly blocked by $\omega$-agatoxin-IVa, and completely blocked by $\omega$-conotoxin MVIIC. The functional properties of class $\mathrm{A} \alpha_{1}$ subunits are distinct from the physiologically defined N-type and P-type calcium channels, but closely resemble those of calcium channels in cerebellar granule cells which have been designated Q-type (Zhang et al., 1993; Randall and Tsien, in press). Functional expression of class $\mathrm{E}\left(\alpha_{\mathrm{tE}}\right)$ in Xenopus oocytes produced rapidly inactivating calcium channels insensitive to high affinity organic and peptide calcium channel blockers (Williams et al., 1992; Soong et al., 1994; Randall and Tsien, in press). The currents conducted by $\alpha_{I E}$ are similar in some respects to T-type calcium currents as well as the recently identified R-type and G1-3 calcium channels in cerebellar granule cells (Forti et al., 1994; Randall and Tsien, in press). However, the precise relationship between $\alpha_{1 \mathrm{E}}$ and native calcium currents remains to be defined. In this study, using antibodies and channel blockers, we have characterized the calcium channels present in AtT-20 cells.

\section{Materials and Methods}

Materials. Tissue culture reagents were from GIBCO, BSA, leupeptin, IBMX, and PMSF from Sigma, PTX from List, $\omega$ AgalVa from Peptides International, leupeptin and $\omega \mathrm{CgTX}$ GVIA from Bachem, ${ }^{3} \mathrm{H}$ WIN 55,212-2 was from New England Nuclear, wCTX MVIIC (SNX 230) from Neurex, somatostain and $\omega$ CgTX GVIA from Peninsula Labs and TTX and GTP from Calbiochem. Synthetic anandamide was provided by both William Devane and Raphael Mechoulam and its purity verified as previously described (Mackie et al., 1993). WIN 55,212-2 and WIN 55,212-3 were gifts from Sterling Research Group.

Cell culture. For electrophysiological recording, A-2 cells were plated on polylysine-coated coverslips and grown in DMEM $+10 \%$ heatinactivated horse serum $+1: 200$ penicillin/streptomycin $+400 \mu \mathrm{g} / \mathrm{ml}$ G418 in a humidified environment with $10 \% \mathrm{CO}_{2}$ at $35^{\circ} \mathrm{C}$. For binding and adenylyl cyclase studies, A-2 cells were grown on $500 \mathrm{~cm}^{2}$ tissue culture plates (NUNC) using the above conditions. Cells were passaged using $0.05 \mathrm{mg} / \mathrm{ml}$ trypsin in phosphate-buffered saline (PBS) and used within 10 passages after the initial clone was isolated.

Cannabinoid receptor expression. PCR amplification was used to introduce restriction sites on each side of the cannabinoid receptor CDNA to facilitate subcloning of the gene from SKR6 (Matsuda et al., 1990) into the pcDNA3 mammalian expression plasmid (Invitrogen). Primers (5'-CGGGATCCAIGAAGTCGATCCTAGATGGCTTG-3' and $5^{\prime}$ CGGGATCCATGGCACAAAAGCAGCAGCTCACAGAGC-3') and pfu polymerase were used to amplify the CB-1 receptor cDNA from the SKR6 plasmid. The resulting PCR product was first subcloned into the BamHI site of pUC19 and then subcloned into the BamHI site of pcDNA3 (CB-1-pcDNA3). Colonies containing CB-1-pcDNA3 were identified by hybridization with a ${ }^{32} \mathrm{P}$-labeled cannabinoid receptor oligonucleotide (PCR sense primer) and the correct orientation was verified by restriction digests with HindIII. AtT20 cells were transfected by the calcium phosphate technique with purified (ProMega) CB-1-pcDNA3. Selection was carried out for $10 \mathrm{~d}$ in G418, several positive colonies expanded and screened by ${ }^{3} \mathrm{H}$-WIN 55,212-2 binding.

Radioligand binding and adenylyl cyclase activity. For binding studies, AtT20 cells transfected with pcDNA3 (control) or CB-1 were grown to confluency in $500 \mathrm{~cm}^{2}$ plates. The monolayers were washed twice with TEM (in mM: 25 Tris-HCl, $6 \mathrm{MgCl}_{2}, 1$ EDTA, $10 \mu \mathrm{M}$ phenylmethylsulfonyl fluride (PMSF), and $1 \mu \mathrm{g} / \mathrm{ml}$ leupeptin, $\mathrm{pH} 7.4$ ) and homogenized in TEM ( $1 \mathrm{ml} /$ plate). The homogenate was centrifuged at $800 \times g$ for $10 \mathrm{~min}$, the resulting pellet homogenized in TEM and spun at $800 \times g$ for $10 \mathrm{~min}$. The combined supernatants were resuspended, centrifuged at $100,000 \times g$ for $1 \mathrm{hr}$ and the pellets were homogenized in TEM at a final protein concentration of $1-5 \mathrm{mg} / \mathrm{ml}$. Membranes $(50$ $\mu \mathrm{g}$ ) were incubated in $20 \mathrm{~mm}$ Hepes and $1 \mathrm{mg} / \mathrm{ml}$ bovine serum albumin (BSA), pH 7.5 (final volume $200 \mathrm{ml}$ ) in $0.325-6 \mathrm{nM}{ }^{3} \mathrm{H}$ WIN 55,212-
2. After $90 \mathrm{~min}$ at $30^{\circ} \mathrm{C}$, the membranes were filtered on a Tomtec Harvester 96 programmed to rapidly filter and wash captured membranes with $3 \times 5 \mathrm{ml}$ Hepes/BSA (Kuster et al., 1993). Specific binding was defined as the fraction of binding displaced by $1 \mu \mathrm{M}$ of unlabeled WIN 55,212-2. Saturation studies were analyzed by computer using the INPLOT program.

For adenylyl cyclase studies, A-2 cells grown on 24 well plates were rinsed twice with PBS and preincubated first with DMEM for $60 \mathrm{~min}$, and then the DMEM, $1 \mathrm{mM}$ isobutylmethylxanthine, and $3 \mu \mathrm{M}$ BSA for $10 \mathrm{~min}$. When appropriate, $100 \mathrm{nM}$ WIN $55,212-2$ or WIN $55,212-3$ was added and the sample incubated for $5 \mathrm{~min}$. The samples were next incubated for $10 \mathrm{~min}$ at $37^{\circ} \mathrm{C}$ with or without $10 \mu \mathrm{M}$ forskolin, lysed with $0.1 \mathrm{~N} \mathrm{HCl}$ and cAMP measured using a scintillation proximity assay kit (Amersham)

Electrophysiological recording. Currrents were recorded using the whole-cell voltage-clamp technique (Hamill et al., 1980). Pipettes were pulled from microhematocrit glass (VWR) and fire polished. For recording, a coverslip containing cells was transferred to a $200 \mu \mathrm{l}$ chamber that was constantly perfused (1-2 $\mathrm{ml} / \mathrm{min}$ ) with the appropriate external solution. Solution reservoirs were selected by means of a series of solenoid valves, and solution changes were accomplished in $<1 \mathrm{~min}$. Voltage protocols were generated and data were digitized, recorded, and analyzed using BASIC-FASTLAB (Indec Systems, Capitola, CA). Junction potentials are uncorrected.

For measuring potassium currents, the pipette solution contained (mM): $130 \mathrm{KCl}, 20$ Hepes, 10 EGTA, $5 \mathrm{MgCl}_{2}, 3 \mathrm{Na}_{2}$ ATP, $0.6 \mathrm{GTP}$, 0.08 leupeptin, $\mathrm{pH} 7.25$ with $\mathrm{KOH}$, while the external solution contained (mM): $20 \mathrm{KCl}, 130 \mathrm{NaCl}$ (or $N$-methylglucamine-NMG), 1 $\mathrm{CaCl}_{2}, 25$ Hepes, 10 glucose, pH 7.35 with $\mathrm{NaOH}$. Fatty acid-free bovine serum albumin (BSA) $(3 \mu \mathrm{M})$ was added to decrease adsorbtion of cannabinoids. In some experiments to increase the amplitude of the potassium currents the concentration of $\mathrm{KCl}$ was increased to 30 or 40 $\mathrm{mM}$ and the concentration of $\mathrm{NaCl}$ or NMG decreased correspondingly, to take advantage of the relationship between $[\mathrm{K}]_{o}$ and the voltage dependence of $\mathrm{K}_{\mathrm{ir}}$ current gating. The $\mathrm{K}_{\mathrm{ir}}$ current was defined as that component of the current sensitive to $1 \mathrm{~mm} \mathrm{Ba}{ }^{2+}$ elicited during the final $150 \mathrm{msec}$ of a $250 \mathrm{msec}$ hyperpolarizing pulse to $-100 \mathrm{mV}$ from a holding potential of $-45 \mathrm{mV}$. Currents were sampled at $1 \mathrm{kHz}$. As the magnitude of the $\mathrm{K}_{\mathrm{ir}}$ current was dependent on cell size, aggregate current data are presented as current densities normalized to cell capacitance.

For measuring calcium currents, the pipette solution contained (mM): $100 \mathrm{CsCl}, 40$ Hepes, 10 EGTA, $5 \mathrm{MgCl}_{2}$, $3 \mathrm{Na}_{2} \mathrm{ATP}, 0.2 \mathrm{GTP}, 0.08$ leupeptin, pH 7.30 with $\mathrm{CsOH}$, while the external solution contained (mM): $160 \mathrm{NaCl}, 5 \mathrm{CaCl}_{2}, 4 \mathrm{KCl}, 1 \mathrm{MgCl}_{2}, 10$ Hepes, 8 glucose, $\mathrm{pH}$ 7.35 with $\mathrm{NaOH}$. Tetrodotoxin (200 nM) was added to block voltagedependent sodium currents and BSA was added to decrease adsorbtion of the cannabinoids, as described above. In experiments using peptide calcium channel blockers, $8 \mu \mathrm{M}$ cytochrome c was substituted for $3 \mu \mathrm{M}$ BSA. This substitution had no effect on $I_{\mathrm{C}}$ or its modulation by WIN 55,212-2 (see Fig. $5 A-C$ ). $I_{\mathrm{Ca}}$ was measured near the end of a $-25 \mathrm{~ms}$ depolarizing pulse to $0 \mathrm{mV}$ from a holding potential of $-90 \mathrm{mV}$ and was defined as that component of the current sensitive to $100 \mu \mathrm{M} \mathrm{CdCl}_{2}$. Currents were sampled at $4 \mathrm{kHz}$

To control for possible response variations with passage number and to avoid one source of systematic bias, experimental and control measurements were alternated whenever possible and concurrent controls were always performed. Where appropriate, data are expressed as mean \pm standard error

Production and purification of peptides and antibodies. The antibodies CNB2, CNC1, and CND1 were prepared as described previously (Hell et al., 1993; Westenbroek et al., 1992). Peptides CNA1 (KYPSSPERAPGREGPYGRE), corresponding to residues 865-881 and CNE2 (KYSASQERSLDEGVSIDG), corresponding to residues 896-911, of the $\alpha_{1}$ subunit of rat brain class $\mathrm{A}$ and $\mathrm{E}$ calcium channels, respectively, plus N-terminal lysine and tyrosine extensions, were synthesized by the solid phase method (Merrifield, 1963). The peptides were purified by reverse-phase HPLC on a Vydac 218TP10 column and their identity verified by amino acid analysis.

Anti-peptide antibodies against the CNA1 or CNE2 peptides were generated using the method described previously (Westenbroek et al., 1992). Briefly, the purified peptide CNA1 or CNE2 was coupled through amino groups with glutaraldehyde to bovine serum albumin (Orth, 1979), dialyzed against PBS, and emulsified in an equal volume of Freund's complete (initial injection) or incomplete adjuvant. At 3 
week intervals, the coupled peptide was injected into multiple subcutaneous sites on New Zealand White rabbits. Antisera were collected after the second injection and tested by enzyme-linked immunosorbent assay using microtiter plates with wells coated with $0.5 \mathrm{mg}$ of peptide (Posnett et al., 1988). Antibodies against CNA1 or CNE2 peptides were purified by affinity chromatography on CNA1 or CNE2 peptides, respectively, which were coupled to $\mathrm{CNBr}$-activated Sepharose. The antiserum $(2.0 \mathrm{ml})$ was bound to the column at $4^{\circ} \mathrm{C}$ overnight, washed with TBS, eluted with $5.0 \mathrm{M} \mathrm{MgCl}_{2}$ and then dialyzed against TBS using a Centriprep 30 (Amicon).

Immunocytochemistry. A-2 cells were grown on $35 \mathrm{~mm}$ plastic petri dishes for 3-5 d. The cells were rinsed briefly in $0.05 \mathrm{M} \mathrm{PB}$ (sodium phosphate, $\mathrm{pH} 7.4$ ), and fixed for 20 min using $4 \%$ paraformaldehyde in $0.1 \mathrm{M}$ PB. The cells were next rinsed with PB briefly followed by 0.05 M PBS (sodium phosphate-buffered saline, pH 7.4) for 30 mins, and then blocked with $10 \%$ Avidin (Vector) in PBS for 30 min. The cells were then rinsed in PBS for 20 mins, blocked with $10 \%$ Biotin (Vector) in PBS for $30 \mathrm{~min}$, rinsed in PBS for $20 \mathrm{~min}$, and then blocked using 5\% normal goat serum in PBS. The cells were incubated overnight at $4^{\circ} \mathrm{C}$ in affinity purified CNA1 (diluted $1: 15$ ), CNB2 (diluted $1: 20$ ), CNC1 (diluted 1:15), CND1 (diluted 1:15), or CNE2 (diluted $1: 20)$ antibodies. All antibodies were diluted in PBS containing $10 \%$ normal goat serum and $0.025 \%$ Triton X-100. The cells were then rinsed with PBS for $45 \mathrm{~min}$ and incubated for $2 \mathrm{hr}$ at room temperature in Biotinylated goat anti-rabbit IgG (diluted 1:400,Vector), rinsed in PBS for $45 \mathrm{mins}$, and then in incubated in Avidin-D-fluorescein (diluted $1: 400$, Vector). The cells were finally rinsed in PBS for $10 \mathrm{~min}, \mathrm{~PB}$ for $20 \mathrm{~min}$, distilled water for $5 \mathrm{~min}$, and then coverslipped using Vectashield (Vector). All samples were viewed and photographed using a Bio-Rad confocal microscope. Controls included incubating cells without primary antibody or blocking the primary antibody by preincubation for 6 to $8 \mathrm{hr}$ with the corresponding peptide $(20-25 \mu \mathrm{M})$. The immunocytochemical reaction was then carried out as described above. The staining patterns reported here were abolished in cells treated without primary antibody or with blocked primary antibody.

\section{Results}

Establishment of a cell line stably expressing $C B-I$

After transfection with CB-1-pcDNA3 and selection in $400 \mu \mathrm{g} /$ ml G418, the clone designated A-2 was chosen for further characterization. Membranes prepared from A-2 cells consistently showed saturable binding for the synthetic cannabinoid ligand ${ }^{3} \mathrm{H}$ WIN 55,212-2 (Fig. 1A), with a $\mathrm{B}_{\max }$ of $864 \pm 13 \mathrm{fmol} / \mathrm{mg}$ protein and a $K_{d}$ of $2.6 \pm 0.7 \mathrm{nM}(n=6)$. Specific binding ranged from 60 to $80 \%$ of the total binding. In contrast, membranes prepared from AtT20 cells transfected with the vector pcDNA3 alone showed no specific binding to ${ }^{3} \mathrm{H}$ WIN 55,212-2 $(n=3$, data not shown). CB-1 expressed in AtT20 cells coupled appropriately to adenylyl cyclase, with $100 \mathrm{nM}$ WIN 55,212-2 inhibiting forskolin-stimulated adenylyl cyclase by about $50 \%$ (Fig. 1B). Its enantiomer, WIN 55,212-3, was inactive (Fig. 1B).

\section{Cannabinoids activate an inwardly rectifying potassium conductance}

Exposure of an A-2 cell to $100 \mathrm{nM}$ WIN 55,212-2 activated a prominent inward current when the cell was hyperpolarized to a potential negative to $\mathrm{E}_{\mathrm{K}}$ in high potassium external (Fig. 2A). This response was seen in more than $90 \%$ of the cells tested (data not shown). The current-voltage relationship for the WIN 55,212-2-induced current showed inward rectification over the voltage range of 0 to $-90 \mathrm{mV}$ (Fig. $2 B$ ). This current was also sensitive to low concentrations of barium (Fig. 2C) (Hagiwara et al., 1978; Dousmanis and Pennefather, 1992). Both of these are features of the inwardly rectifying potassium current activated by somatostain and muscarinic agonists previously identified in these cells (Pennefather et al., 1988; Jones, 1992). Thus, we will refer to this current as inwardly rectifying potassium current or $\mathrm{K}_{\mathrm{ir}}$ current. WIN 55,212-2 failed to increase $\mathrm{K}_{\mathrm{ir}}$ cur-

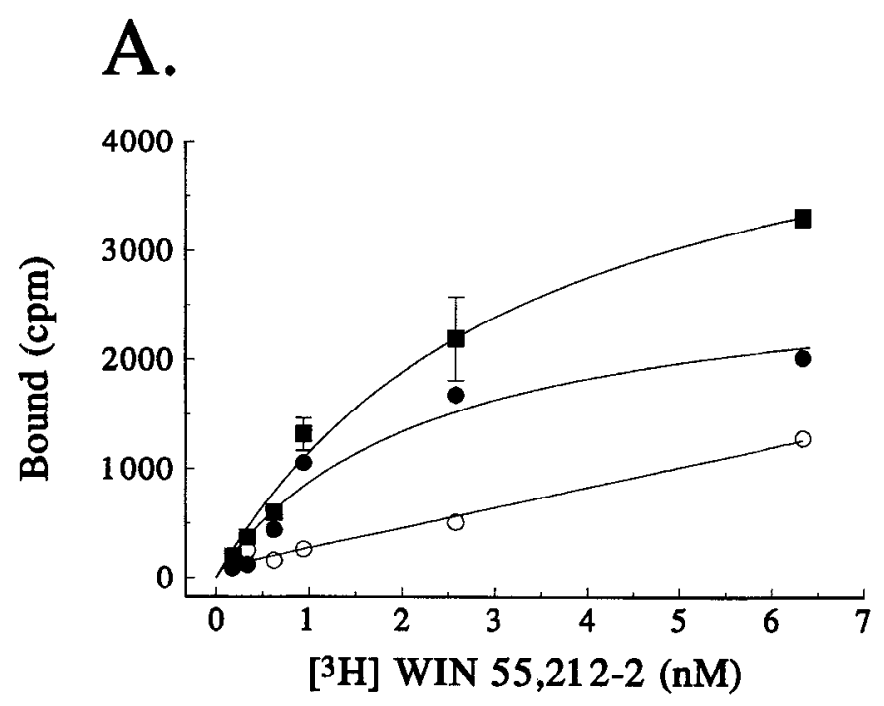

B.

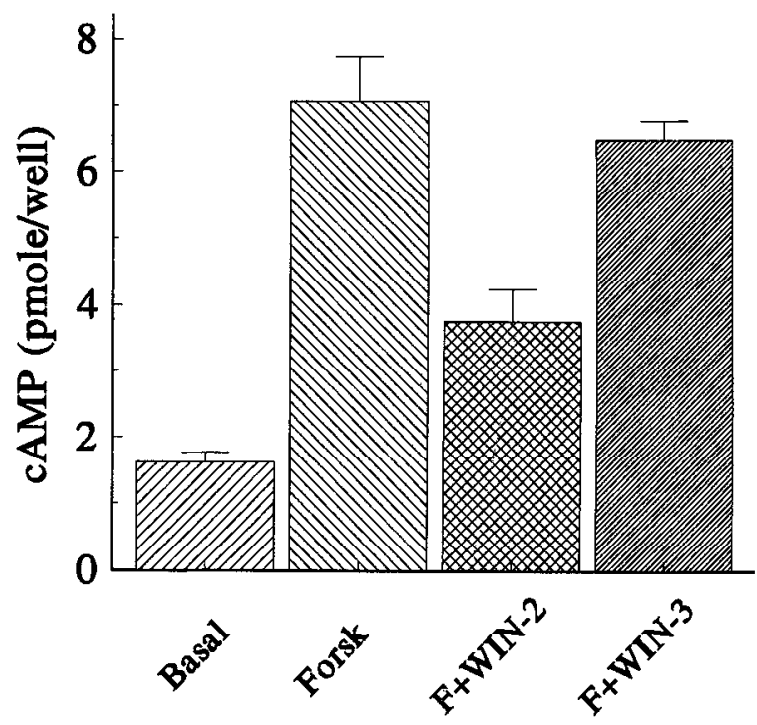

Figure 1. Functional expression of $\mathrm{CB}-1$ cannabinoid receptor in AtT20 cells. A, Cannabinoid receptor expressed in AtT20 cells shows saturable binding. Saturation isotherm for binding of ${ }^{3} \mathrm{H}$-WIN $55,212-2$ to membranes prepared from A-2 cells. Nonspecific binding (open circles) is ${ }^{3} \mathrm{H}$-WIN 55,212-2 bound in the presence of $1 \mu \mathrm{M}$ WIN 55,2122. Squares, Total binding. Solid circles, specific binding. $B, \mathrm{CB}-1$ expressed in A-2 cells can inhibit adenylyl cyclase. Preincubation with $100 \mathrm{nM}$ WIN 55,212-2 decreased forskolin $(F)$-stimulated synthesis of cAMP ( $p<0.02$ vs forskolin alone), while the inactive enantiomer, WIN 55,212-3 was ineffective $(p<0.01$ vs forskolin + WIN 55,2122).

rent in AtT20 cells transfected with the pcDNA3 plasmid alone $(0.09 \pm 0.18 \mathrm{pA} / \mathrm{pF}, n=4$, data not shown). However, $200 \mathrm{~nm}$ somatostatin robustly activated $\mathrm{K}_{\mathrm{ir}}$ current in these cells as expected (Pennefather et al., 1988) (data not shown).

In N18 neuroblastoma cells and NG108-15 neuroblastoma glioma cells WIN 55,212-2-mediated inhibition of N-type $I_{\mathrm{Ca}}$ is half-maximal at about $10 \mathrm{nM}$ (Mackie and Hille, 1992; Mackie et al., 1993). Similarly, in A-2 cells WIN 55,212-2 potently activated $\mathrm{K}_{\mathrm{ir}}$ current with an EC.50 of $12 \pm 4 \mathrm{nM}$ (Fig. 2D). Binding and activation of $\mathrm{K}_{\mathrm{ir}}$ current did not show marked coopera- 
A.

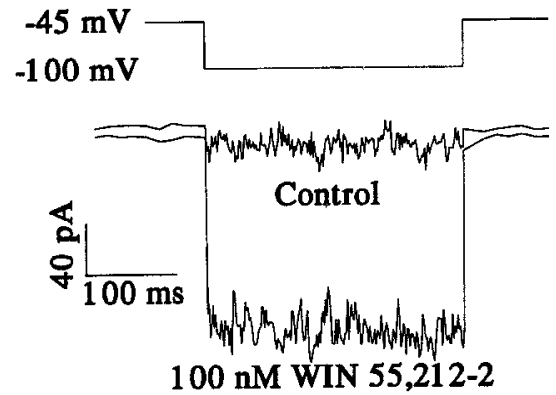

B.

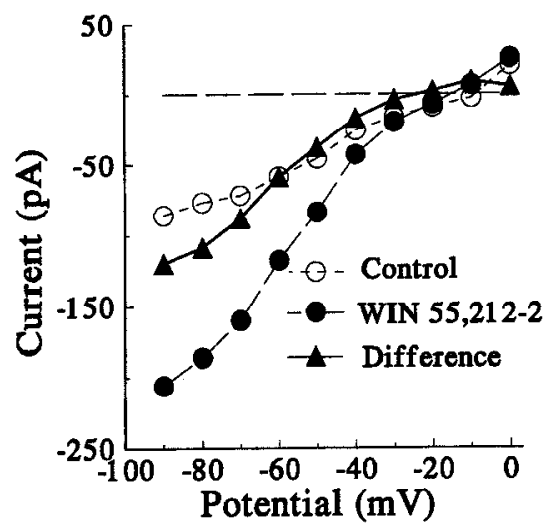

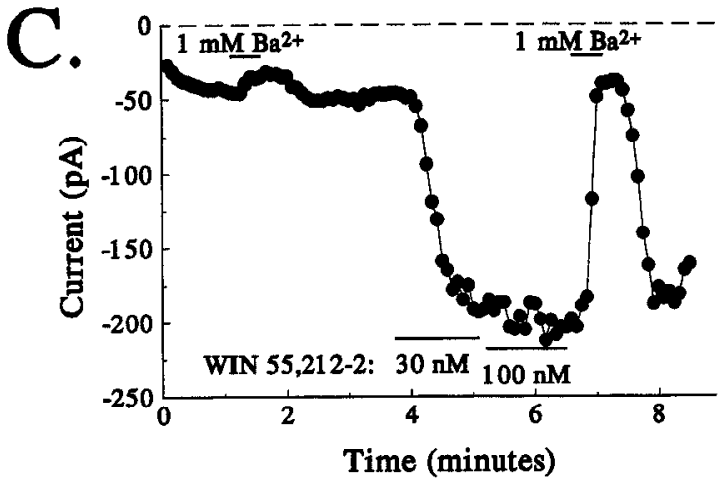

D.

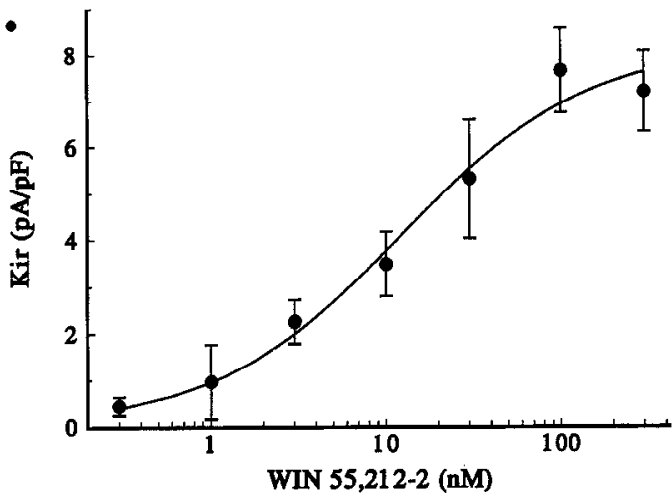

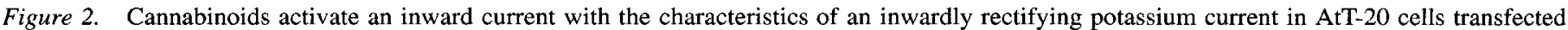

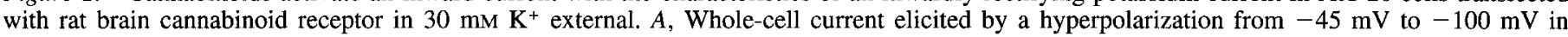

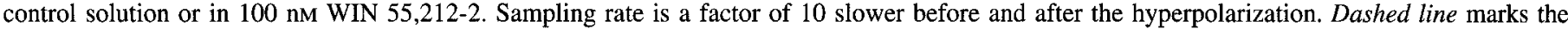

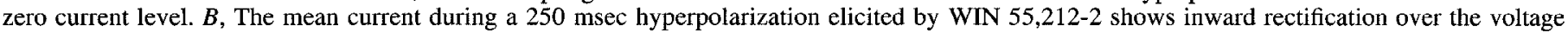

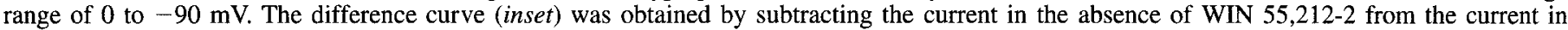

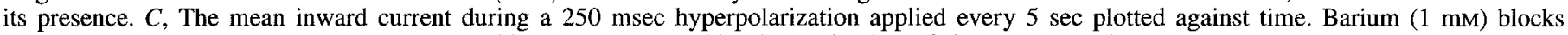

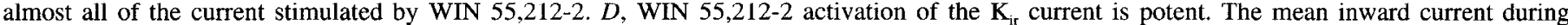

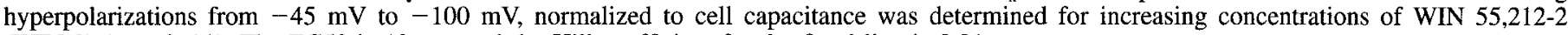
(WIN-2) ( $n=3-11)$. The EC50 is $12 \mathrm{nM}$, and the Hill coefficient for the fitted line is 0.81 .

tivity; the Hill coefficient for activation was $0.81 \pm 0.17$. As expected for a cannabinoid receptor-mediated process, WIN $55,212-3$, the inactive enantiomer of WIN 55,212-2, was ineffective in increasing $\mathrm{K}_{\mathrm{ir}}$ current in A-2 cells $(0.16 \pm 0.09 \mathrm{pA} /$ $\mathrm{pF}, n=4$, data not shown). Cannabinoid activation of $\mathrm{K}_{\mathrm{ir}}$ current was abolished by overnight incubation with $200 \mathrm{ng} / \mathrm{ml}$ pertussis toxin (PTX) $(-0.1 \pm 0.1 \mathrm{pA} / \mathrm{pF}, n=4$, data not shown), implicating involvement of $G$ proteins of the $G_{i}$ or $G_{o}$ class. In 40 $\mathrm{mM}$ external $\mathrm{K}^{+}, 200 \mathrm{nM}$ somatostatin, $100 \mathrm{nM}$ WIN 55,212-2, and $10 \mu \mathrm{M}$ oxotremorine-m activated $\mathrm{K}_{\mathrm{ir}}$ current by $32.3 \pm 4.5$ $\mathrm{pA} / \mathrm{pF}, n=6 ; 11.5 \pm 2.3 \mathrm{pA} / \mathrm{pF}, n=9 ;$ and $8.6 \pm 4.0 \mathrm{pA} / \mathrm{pF}$, $n=7$, respectively, at $-100 \mathrm{mV}$ (data not shown). Thus somatostatin appears to be a more efficacious activator of $\mathrm{K}_{\mathrm{ir}}$ in these cells than either WIN 55,212-2 or oxotremorine-m. As AtT-20 cells only express about $200 \mathrm{fmol} / \mathrm{mg}$ of somatosatin receptors (about 19,000 receptors/cell) (Thermos and Reisine, 1988), the increased efficacy of somatostatin cannot be due to a higher receptor density and may occur at the level of the $G$ protein.

Anandamide, an endogenous ligand for the brain cannabinoid receptor has been identified, isolated, synthesized and characterized (Devane et al., 1992; Felder et al., 1993; Mackie et al., 1993). In N18 neuroblastoma cells, anandamide has a lower intrinsic efficacy than the potent synthetic cannabinoids CP 55,940 and WIN 55,212-2 (Mackie et al., 1993), acting as a partial agonist for inhibition of $\mathrm{N}$-type $I_{\mathrm{Ca}}$. Thus, it was of interest to see if anandamide acts as a partial agonist in activation of $K_{i r}$ current. This appears not to be the case as $\mathrm{K}_{\mathrm{ir}}$ current is activated to a similar cxtent by application of $300 \mathrm{nM}$ anandamide or by application of $100 \mathrm{nM}$ WIN 55,212-2 (Fig. $3 A, B$ ).

\section{Cannabinoids inhibit $\mathrm{I}_{C a}$ via a voltage-dependent and PTX-} sensitive pathway

In neuroblastoma cell lines cannabinoids inhibit $\mathrm{N}$-type $I_{\mathrm{Ca}}$ (Caulfield and Brown, 1992; Mackie and Hille, 1992; Mackie et al., 1993). We found that cannabinoids also inhibit high voltageactivated $I_{\mathrm{Ca}}$ in A-2 cells (Fig. 4A,C). This response was seen in more than $95 \%$ of the cell that expressed $I_{\mathrm{Ca}}$ (data not shown). A common form of high voltage-activated $I_{\mathrm{Ca}}$ modulation is a voltage-dependent inhibition that can be transiently overcome by application of large depolarizing prepulses (Bean, 1989; Marchetti et al., 1986), that is, prepulse facilitation. In mammalian cells, many receptors coupled to PTX-sensitive G proteins, including the cannabinoid CB-1 receptor, produce such voltagedependent inhibition (Ikeda, 1991; Kasai, 1992; Mackie et al., 1993). Voltage-dependent inhibition can be assessed by first subjecting the cell to a brief depolarization to $0 \mathrm{mV}$ to obtain the baseline calcium current. After a pause of $2 \mathrm{sec}$, the cell is 
Figure 3. Anandamide, also activates the $\mathrm{K}_{\text {ir }}$ current. $A$, The mean inward current during a $250 \mathrm{msec}$ hyperpolarization applied every $5 \mathrm{sec}$ from a holding potential of $-45 \mathrm{mV}$ to -100 $\mathrm{mV}$ plotted against time. $300 \mathrm{~nm}$ Anandamide (ANAND) elicits a large inward current. Subsequent coapplication of $100 \mathrm{nM}$ WIN 55,212-2 (WIN) does not increase this current. The fine line corresponds to the holding current at $-45 \mathrm{mV}, B$, Comparison of $\mathrm{K}_{\mathrm{ir}}$ current activation from a number of cells. The number of cells tested for each condition is indicated by the number in parentheses. Anandamide activated $\mathrm{K}_{\mathrm{ir}}$ current to the same extent as WIN $55,212-2$.
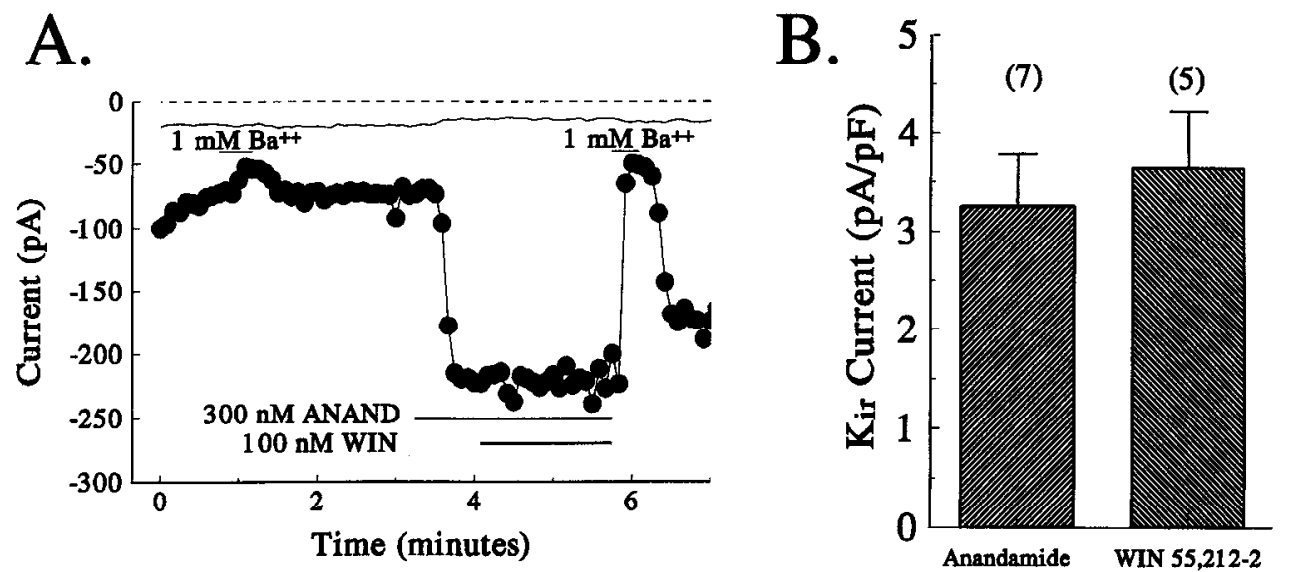

strongly depolarized (to ca. $100 \mathrm{mV}$ ) to remove any voltagedependent inhibition, stepped back to the holding potential for a few milliseconds and then stepped to $0 \mathrm{mV}$ to measure the facilitated calcium current (see the voltage protocol in Fig. $4 A$ as an example). A comparison of the $I_{\mathrm{Ca}}$ during the first and second test pulses will give a measure of the facilitation that occurs during the depolarizing prepulse. During the application of an agonist that shows voltage-dependent inhibition, the reduction of $I_{\mathrm{Ca}}$ during the first, baseline pulse will be greater than during the second, facilitated pulse. The degree of relief from agonist-induced inhibition during the facilitated pulse is a measure of the voltage dependence of the inhibition.

The effect of cannabinoids on $I_{\mathrm{Ca}}$ in A-2 cells was determined using the double pulse voltage protocol shown in Figure $4 A$. Bath application of $100 \mathrm{nM}$ WIN 55,212-2 inhibited about $25 \%$ of the current during the first test pulse (Fig. $4 A$ ), but only $10 \%$ of the current during the second, facilitated pulse. On average, inhibition of $I_{\mathrm{Ca}}$ by $100 \mathrm{nM}$ WIN 55,212-2 was $60 \pm 7 \%$ voltage dependent $(n=6)$ (data not shown). Application of $100 \mathrm{nM}$ WIN 55,212-2 to AtT20 cells transfected with pcDNA3 alone (mock)
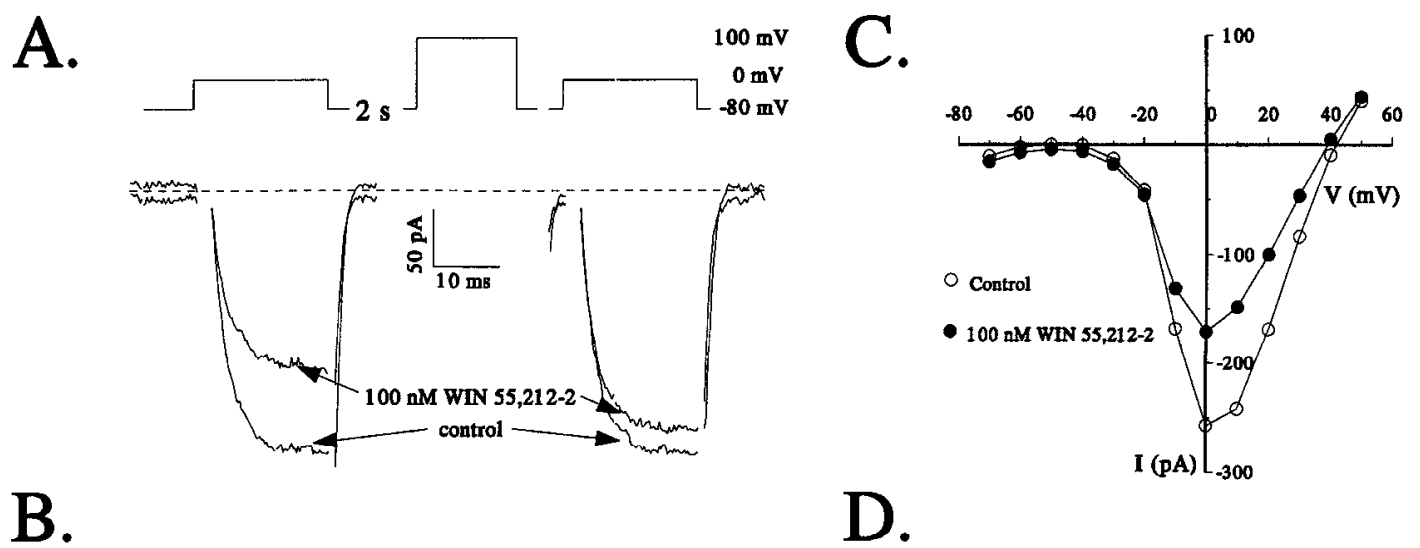

B.

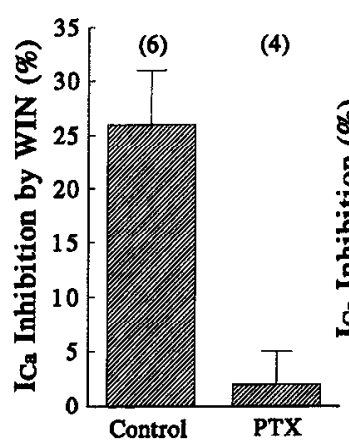

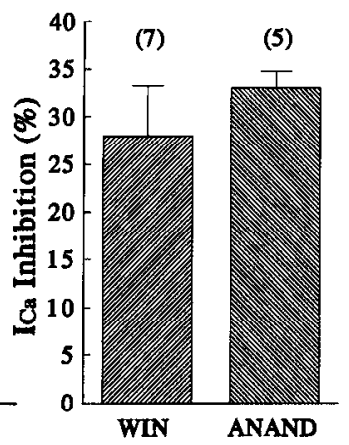

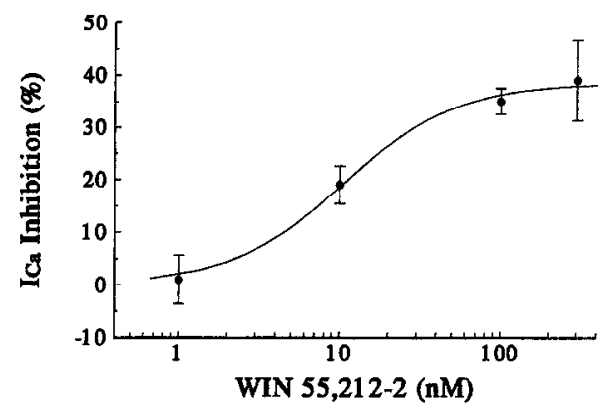

Figure 4. WIN 55,212-2 inhibits a high voltage-activated $I_{\mathrm{Ca}}$ in AtT20 cells expressing rat brain cannabinoid receptor in a voltage- and PTXsensitive fashion. $A$, Calcium currents were measured using a double pulse protocol. After a pause of 2 sec, the first test pulse was followed by a $50 \mathrm{msec}$ depolarization to $100 \mathrm{mV}$, a $5 \mathrm{msec}$ repolarization to $-80 \mathrm{mV}$ and a second test pulse to $0 \mathrm{mV} ; 100 \mathrm{nM}$ WIN $55,212-2$ inhibited approximately $25 \%$ of the $I_{\mathrm{Ca}}$ during the first pulse, but only $10 \%$ of the $I_{\mathrm{Ca}}$ during the second pulse indicating voltage dependence. Traces were $\mathrm{Cd}^{2+}(100 \mu \mathrm{M})$ subtracted. B:Left, overnight incubation with $500 \mathrm{ng} / \mathrm{ml}$ PTX effectively blocked modulation of $I_{\mathrm{Ca}}$ in AtT20 cells expressing rat CB-1. Right, $300 \mathrm{nM}$ anandamide was as effective as $100 \mathrm{nM}$ WIN 55,212-2 in inhibiting $I_{\mathrm{Ca}}$. $C$, Current-voltage relationship of $I_{\mathrm{Ca}}$ in AtT20 cells does not reveal a low voltage-activated $I_{\mathrm{Ca}} . D$, Concentration response for WIN 55,212-2 inhibition of $I_{\mathrm{Ca}}$ in AtT20 cells expressing CB-1. Inhibition was half-maximal at $11 \mathrm{~nm}$. 

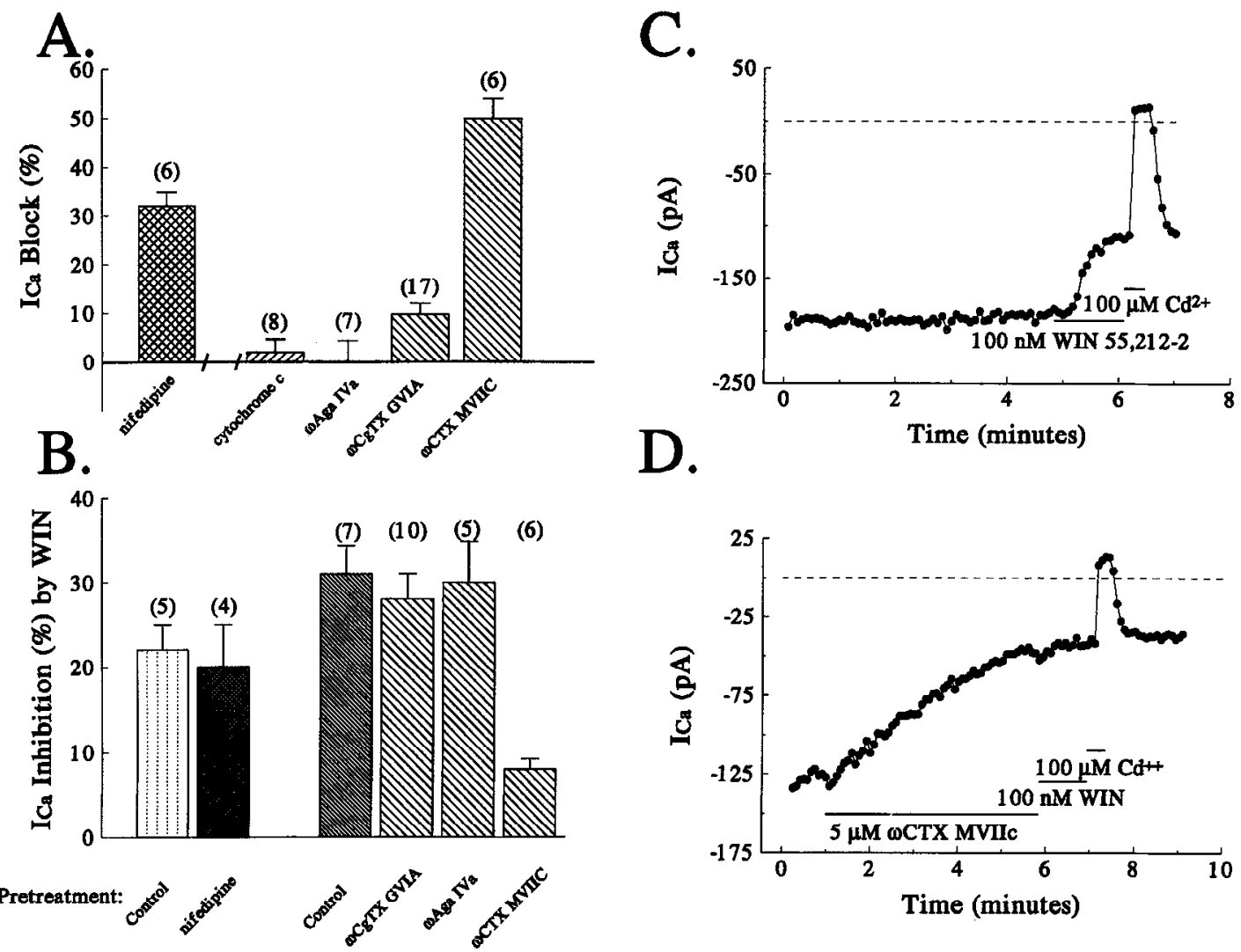

Figure 5. Calcium currents present in AtT20 cells expressing rat brain cannabinoid receptor and their modulation by calcium channel antagonists. $A$, Mean suppression of $I_{\mathrm{Ca}}$ by $2 \mu \mathrm{M}$ nifedipine, $8 \mu \mathrm{M}$ cytochrome c, $200 \mathrm{nM} \omega$ Aga IVa, $1 \mu \mathrm{M} \omega \mathrm{CgTX}$ GVIA, and $5 \mu \mathrm{M} \omega \mathrm{CTX}$ MVIIC. Nifedipine block is expressed as a percentage of whole cell $I_{\mathrm{Ca}}$, while block by the remaining agents are expressed as percentage of whole cell $I_{\mathrm{Ca}}$ after treatment of the cell with $2 \mu \mathrm{M}$ nifedipine; $8 \mu \mathrm{M}$ cytochrome $\mathrm{c}$ was used as the carrier for $\omega$ Aga IVa, $\omega \mathrm{CgTX}$ GVIA and $\omega \mathrm{CTX}$ MVIIC. $B$, Inhibition of $I_{\mathrm{Ca}}$ by WIN 55,212-2 after treatment with calcium channel antagonists. Left two bars, preapplication of $2 \mu \mathrm{M}$ nifedipine before treatment with $100 \mathrm{nM}$ WIN 55,212-2 does not reduce inhibition by WIN 55,212-2. Right four bars, cells were continuously exposed to $2 \mu \mathrm{M}$ nifedipine, then the indicated calcium channel antagonist, and finally $100 \mathrm{nM}$ WIN 55,212-2. Inhibition by WIN 55,212-2 was normalized to $I_{\mathrm{Ca}}$ in nifedipine before application of the second calcium channel antagonist. Modulation of $I_{\mathrm{Ca}}$ by $100 \mathrm{nM}$ WIN 55,212-2 in cells exposed to $8 \mu \mathrm{M}$ cytochrome c $(C)$ and $5 \mu \mathrm{M} \omega \mathrm{CTX} \mathrm{MVIIC}(D)$.

did not inhibit $I_{\mathrm{Ca}}(0.9 \pm 1.1 \%, n=4$, data not shown). Similarly, as was found for activation of $\mathrm{K}_{\mathrm{ir}}$, modulation of $I_{\mathrm{Ca}}$ by $100 \mathrm{nM}$ WIN 55,212-2 is mediated via $G$ protein(s) of the $G_{i}$ or $\mathrm{G}_{\mathrm{o}}$ class, as overnight incubation of A-2 cells with $500 \mathrm{ng} / \mathrm{ml}$ PTX abolished WIN 55,212-2-induced $I_{\mathrm{Ca}}$ inhibition (Fig. $4 B$, left). Application of $300 \mathrm{~nm}$ anandamide inhibited $I_{\mathrm{Ca}}$ as efficaciously as $100 \mathrm{nM}$ WIN 55,212-2 (Fig. $4 B$, right). Inhibition of $I_{\mathrm{Ca}}$ by WIN $55,212-2$ was potent, being half-maximal at $11 \mathrm{nM}$ (Fig. 4D), and noncooperative, with a Hill coefficient of 1.1.

\section{Cannabinoids inhibit a non- $L, N, P, T$ calcium current}

We next determined which subtype(s) of $I_{\mathrm{Ca}}$ cannabinoids inhibited in A-2 cells. Previous studies have found that AtT20 cells do not express a functional low-voltage-activated, or T-type, calcium current (Luini et al., 1986; Surprenant et al., 1992). Similarly, A-2 cells do not appear to express this current (Fig. 4C). Although the classification of high voltage-activated calcium currents in excitable cells is still developing, a classification useful for interpreting data from electrophysiological experiments is based on the sensitivity of different calcium currents to dihydropyridines and peptide toxins. For this study, we defincd L-type calcium current as that $I_{\mathrm{Ca}}$ sensitive to the dihydropyridine, nifedipine; $P$ type $I_{\mathrm{Ca}}$ was defined as that component of the current sensitive to low concentrations of the spider toxin, $\omega$ Aga
IVa; $N$-type $I_{\mathrm{Ca}}$ was defined as the current sensitive to the conus toxin, $\omega$ CgTX GVIA. In many neurons, a significant high voltage-activated $I_{\mathrm{Ca}}$ remains after treatment with a cocktail of the above blockers. This current is often sensitive to the conus toxin, $\omega C T X$ MVIIC, appears to play a role in neurotransmitter relcase, can be modulated by $G$ protein coupled receptors, and has tentatively been labeled as Q-type $I_{\mathrm{Ca}}$ (Adams et al., 1993; Sather et al., 1993; Wheeler et al., 1994; Zhang et al., 1993). The residual high voltage-activated current after treatment with dihydropyridines and $\omega \mathrm{CTX}$ MVIIC has been designated "R-type" by some investigators (Randall and Tsien, in press) although this current might actually consist of several components.

We first pharmacologically determined the high voltage-activated calcium current types present in AtT-20 cells. Nifedipine $(2 \mu \mathrm{M})$ blocked about a third of the whole cell $I_{\mathrm{Ca}}$ elicited by a depolarization to $0 \mathrm{mV}$ from a holding potential of $-90 \mathrm{mV}$ (Fig. $5 A$ ). In cells pretreated with $2 \mu \mathrm{M}$ nifedipine, $200 \mathrm{nM} \omega$ Aga IVa was ineffective in blocking $I_{\mathrm{Ca}}$ (Fig. $5 A$ ), while $1 \mu \mathrm{M}$ $\omega \mathrm{CgTX}$ GVIA blocked less than $10 \%$ of $I_{\mathrm{Ca}}$ (Fig. $5 A$ ). Therefore, AtT-20 cells don't express P-type $I_{\mathrm{Ca}}$ and express low levels of N-type $I_{\mathrm{Ca}}$. However, $5 \mu \mathrm{M}$ $\omega \mathrm{CTX}$ MVIIC slowly blocked approximately $50 \%$ of the $I_{\mathrm{Ca}}$ in these cells (Fig. $5 A, D$ ). Inhibition during $\omega$ CTX MVIIC application did not appear to he a consequence of rundown as calcium currents were fairly stable un- 
der the present recording conditions (Fig. 5A,C). Thus AtT-20 cells are distinctive among cell lines examined thus far in that they express a significant Q-type $I_{\mathrm{Ca}}$.

We next determined the component of $I_{\mathrm{Ca}}$ cannabinoids inhibited. WIN 55,212-2 does not appear to inhibit L-type $I_{\mathrm{Ca}}$, as block of these channels by $2 \mu \mathrm{M}$ nifedipine does not decrease the fraction (normalized to prenifedipine levels) of $I_{\mathrm{Ca}}$ inhibited by $100 \mathrm{nM}$ WIN 55,212-2 (Fig. 5B). As an expected consequence of their modest effects on whole cell $I_{\mathrm{Ca}}$, prior application of $200 \mathrm{nM} \omega \mathrm{Aga}$ IVa or $1 \mu \mathrm{M} \omega \mathrm{CgTX}$ GVIA did not significantly alter $I_{\mathrm{Ca}}$ inhibition by $100 \mathrm{nM}$ WIN 55,212-2 (Fig. 5B). In contrast, prior treatment by $5 \mu \mathrm{M} \omega \mathrm{CTX}$ MVIIC reduced subsequent inhibition by $100 \mathrm{nM}$ WIN 55,212-2 from $31 \pm 3.3 \%$ $(n=7)$ to $8 \pm 1.2 \%(n=6)$ (Fig. $5 B, D)$. Thus the majority of the WIN 55,212-2-inhibited $I_{C a}$ is carried via Q-type calcium channels sensitive to $\omega \mathrm{CTX}$ MVIIC but insensitive to nifedipine, $\omega$ Aga IVa, or $\omega$ CgTX GVIA.

\section{Immunocytochemical identification of class $A, B, C, D$, and $E$ calcium channels in A-2 cells}

Immunocytochemistry was carried out to further verify the presence of L-, N-, and Q-type calcium channels in the A-2 cell line, using anti-peptide antibodies specific to class A (CNA1), class B (CNB2), class C (CNC1), class D (CND1), or class E (CNE2) neuronal calcium channels. The biochemical properties and localization of CNA1 and CNB2 antibodies in rat brain have been reported previously (Westenbroek et al., 1992, 1995; Hell et al., 1993). Using the CNA1 antibody we observed a relatively dense pattern of staining in the cell hody and along the extensions of the A-2 cells (Fig. 6A). Occasionally there was staining in the foot processes of the cells, however, staining in this region was variable. The pattern of CNB2 antibody localization (Fig. $6 B$ ) was similar to that observed for the CNA1 antibody. There was specific CNB2 staining in the cell body, along the extensions and in the foot process. The CNB2 staining in the foot process was much more common than staining of this region with the CNA1 antibody. The pattern of staining for CNA1 and CNB2 antibodies appears to be punctate, suggestive of clustering of calcium channels. In addition, the staining appears to be mainly in the membrane as suggested by a $\mathrm{z}$-series through several cells at $1 \mu \mathrm{m}$ steps. The immunoreactivity observed with the $\mathrm{CNC} 1$ and the CND1 antibodies was localized predominatly to the cell body and in the proximal portion of the extensions (Fig. 6C,D). Occasionally, there was relatively faint staining of CND1 in the foot process. The staining with the $\mathrm{CNCl}$ also appeared to he punctate. In N18 neuroblastoma cells the high-voltage-activated $I_{\mathrm{Ca}}$ is blocked by a combination of $2 \mu \mathrm{M}$ nifedipine and $1 \mu \mathrm{M}$ $\omega$ CgTX GVIA, implying that class B, C, and/or D, but not A, calcium channels are functionally expressed (Mackie et al., 1993). Consistent with this electrophysiological observation, N18 cells were intensely labeled with antibodies against class $\mathrm{B}, \mathrm{C}$, and D channels, but not with antibodies against class A channels (data not shown).

Antipeptide antibodies to class E calcium channels (Yokoyama et al., 1995) were also used to investigate the presence of other voltage-dependent calcium channels in A-2 cells. Using CNE2 antibodies we observed a relatively dense pattern of staining in the cell body of A-2 cells (Fig. $6 E$ ). There was also weak CNE2 staining along the extensions with relatively little staining observed in the foot process. We observed no staining with the CNE2 antibody in N18 cells. The current electrophysiological studies suggest that R-type currents are present in A-2 cells and earlier work demonstrates a prominent T-type current in $\mathrm{N}-18$ cells (Mackie et al., 1993; Mackie, unpublished observations). Thus, our immunocytochemical results are consistent with the hypotheses that class E calcium channels mediate "R-type" currents in A-2 cells and they do not mediate T-type currents in N18 cells. Control sections in which the primary antibody was omitted (Fig. $6 F$ ) indicate that the staining observed using the CNA1, CNB2, CNC1, CND1, or CNE2 antibodies is specific.

Collectively our studies confirm the presence of class A (Qtype), class B (N-type), class C and D (L-type), and class E ( $R$ type?) calcium channels in the A-2 cells. Since this is not quantitative immunocytochemistry, the differences in the relative amount of staining among the antibodies can not be interpreted as absolute differences in the amount of channel present. The staining depends on such variables as the titer of the antibodies and the access of the antibody to the antigenic site.

\section{Discussion}

Here we have found that cannabinoids activate a $\mathrm{K}_{\mathrm{ir}}$ current and inhibit a Q-type $I_{\mathrm{Ca}}$ in AtT20 cells transfected with the rat brain cannabinoid receptor. Thus, it is likely that cannabinoids will do the same in neurons expressing the cannabinoid receptors, these ion channels, and N-type calcium channels. Our favored interpretation of the results of these and earlier studies is that activation of the cannabinoid receptor decreases the excitability of those neurons expressing it. Specifically, inhibition of $\mathrm{N}$ - and Q-type calcium currents will decrease the likelihood of neurotransmitter release and successful synaptic transmission as well as suppressing other calcium-dependent processes. Activation of $\mathrm{K}_{\mathrm{ir}}$ currents will decrease excitability by holding the membrane potential negative to the activation threshold for sodium and calcium channels making pre- and postsynaptic depolarization, action potential generation, and impulse propagation less likely.

AtT20 cells transfected with the rat brain cannabinoid receptor (A-2 cells) expressed functional cannabinoid receptors as evidenced by the development of specific WIN 55,212-2 binding sites and the ability of WIN 55,212-2 to inhibit forskolin-stimulated adenylyl cyclase. The inward current activated by cannabinoids in A-2 cells has the characteristics of a $\mathrm{K}_{\mathrm{ir}}$ currentit was sensitive to $1 \mathrm{mM} \mathrm{Ba}^{2+}$ and its current-voltage relationship showed inward rectification (Fig. $2 B$ ). Activation of $\mathrm{K}_{\mathrm{ir}}$ current by cannabinoids in A-2 cells appears similar in most regards to activation of similar currents in other cells and neurons as it is mediated by a PTX-sensitive G protein (North, 1989).

The endogenous cannabinoid, anandamide, has a lower intrinsic efficacy than the potent synthetic cannabinoids, WIN 55,212-2 or CP 55,940 (Mackie et al., 1993). In N18 cells, anandamide acts as a partial agonist in inhibiting N-type $I_{\mathrm{C} a}$. In this study partial agonism by anandamide was not found for either activation of $\mathrm{K}_{\mathrm{ir}}$ current or inhibition of Q-type $I_{\mathrm{Ca}}$. This might be a consequence of A- 2 cells having a higher density of CB-1 receptors than $\mathrm{N} 18$ cells $(<100 \mathrm{fmol} / \mathrm{mg}$, data not shown), or because different $\mathrm{G}$ proteins transduce the response (Hoyer and Boddeke, 1993). In either case, because of the high density of cannabinoid receptor expression in many brain regions, anandamide likely acts as a full agonist in activation of $\mathrm{K}_{\mathrm{ir}}$ current or inhibition of Q-type $I_{\mathrm{Ca}}$ in those regions.

Cannabinoids inhibit N-type calcium channels in N18 and NG108-15 cells (Mackie and Hille, 1992; Mackie et al., 1993), two cell lines descended from a murine peripheral neuroblastoma. N-type $I_{\mathrm{Ca}}$ mediates a portion of neurotransmitter release at some mammalian CNS synapses (Takahashi and Momiyama, 

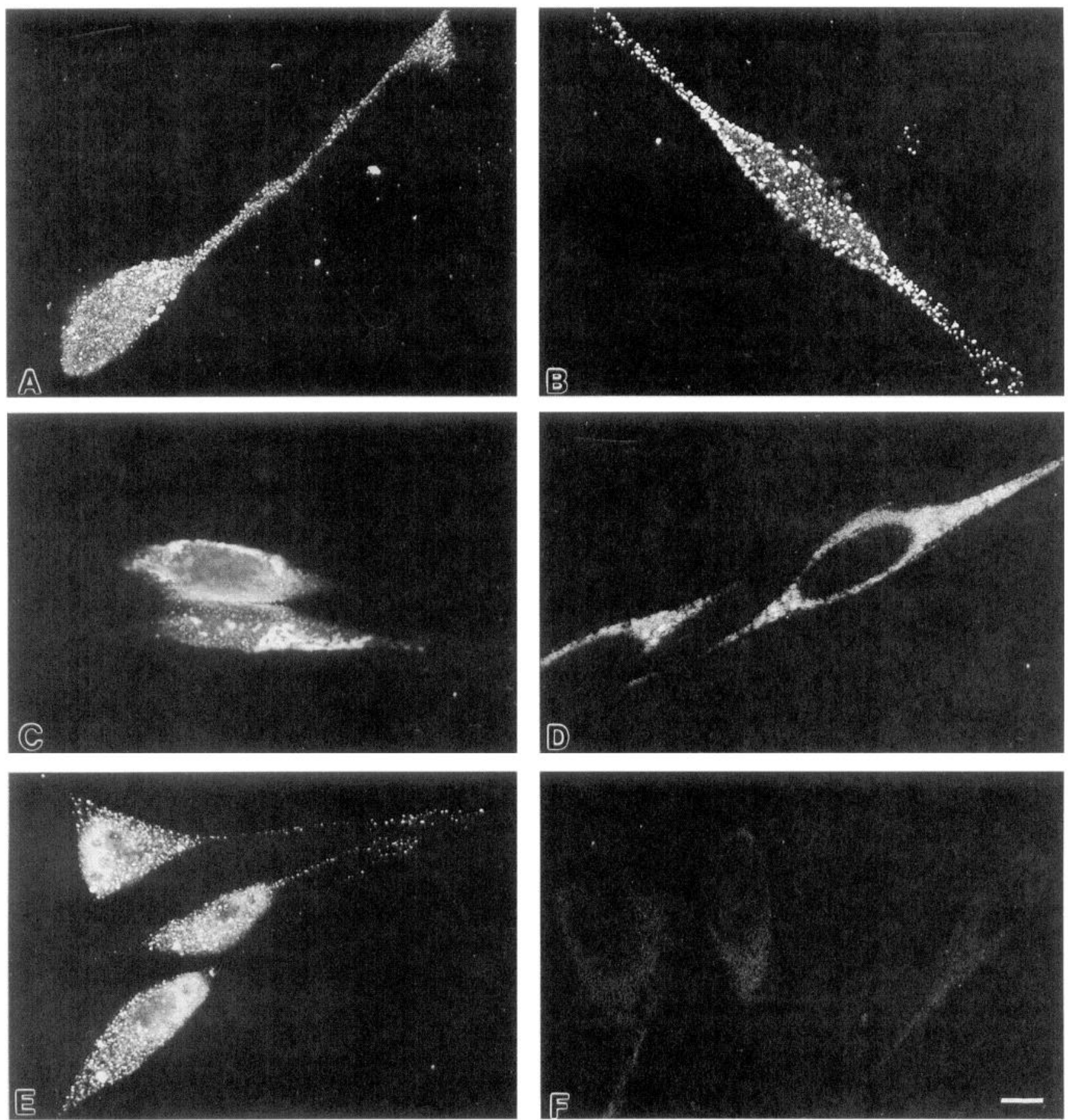

Figure 6. Localization of class A-E calcium channels in A-2 cells. A-2 cells were stained using the immunofluoresence technique as described in Materials and Methods. A, A-2 cells stained with CNA1 antibody to rat brain class A calcium channels. B, A-2 cells stained with the CNB2 antibody against the rat brain class B N-type calcium channels. $C$, Cells labeled with $\mathrm{CNC1}$ demonstrating the presence of class $\mathrm{C}$ L-type calcium channels. $D$, A-2 cell line labeled with class D L-type calcium channels. $E$, A-2 cells stained with CNE2 antibody against the rat brain class E calcium channels. $F$, A-2 cells with primary antibody omitted. Scale bar, $10 \mu \mathrm{m}$.

1993; Turner et al., 1993; Wheeler et al., 1994). It is likely that cannabinoid agonists decrease neurotransmitter release in presynaptic terminals expressing cannabinoid receptors and N-type $I_{\text {Ca. }}$. Recent studies have implicated Q-, O-, or possibly other types of $I_{\mathrm{Ca}}$ (defined as being insensitive to $\omega \mathrm{CgTX}$ GVIA and dihydropyridines, sensitive to only high concentrations of $\omega \mathrm{Aga}$ IVa, and sensitive to wCTX MVIIC; Adams et al., 1993; Zhang et al., 1993) and P-type $I_{\mathrm{Ca}}$ (sensitive to low concentrations of
wAga IVa) as major facilitators of neurotransmission at mammalian CNS synapses (Wheeler et al., 1994). It has been proposed based on differential toxin sensitivities that the Q-type current described in cerebellar granule cells (Zhang et al., 1993) corresponds to the $\mathrm{Ba}^{2+}$ current described in Xenopus oocytes expressing a rabbit $\alpha_{1 \mathrm{~A}}$ (together with rabbit $\alpha_{2} / \delta$ and $\beta$ subunits) calcium channel (Sather et al., 1993). The G protein modulation of Q-type $I_{\mathrm{Ca}}$ found in the current study appears to have at least 
two properties in common with modulation of N-type $I_{\mathrm{Ca}}$. In particular, it is voltage dependent and PTX-sensitive (Mintz and Bean, 1993; Swartz, 1993; Wheeler et al., 1994; current study).

The pharmacology of the $I_{\mathrm{Ca}}$ inhibited by cannabinoids in CB1-transfected AtT-20 cells is similar to that described for Q-type $I_{\mathrm{Ca}}$ (Zhang et al., 1993; Randall and Tsien, in press). As activation of $\mathrm{m}_{4}$ muscarinic and somatostatin receptors also inhibit most of the dihydropyridine-insenstive $I_{\mathrm{Ca}}$ in these cells in a voltage-dependent fashion (data not shown), it is likely that these receptors can also inhibit Q-type $I_{\mathrm{Ca}}$ in neurons. It is possible that Q-type current may actually be composed of several components, but the present operational definition of Q-type $I_{\mathrm{Ca}}$ as a $I_{\mathrm{Ca}}$ insensitive to $\omega \mathrm{CgTX}$ GVIA and dihydropyridines, sensitive to high concentrations of $\omega \mathrm{Aga}$ IVa, and sensitive to $\omega \mathrm{CTX}$ MVIIC is useful. There are two differences between Q-type $I_{\mathrm{Ca}}$ previously defined (Zhang et al., 1993; Randall and Tsien, in press) and our present results. The first is that $200 \mathrm{nM} \omega \mathrm{Aga}$ IVa was ineffective at blocking $I_{\mathrm{Ca}}$ in our experiments, whereas this concentration of $\omega$ Aga IVa did block a portion of the $I_{\mathrm{Ba}}$ in oocytes expressing rabbit $\alpha_{1 \mathrm{~A}}$ (Sather et al., 1993). This may be a consequence of a charge carrier, species, or expression difference. The second is that $5 \mu \mathrm{M} \omega \mathrm{CTX}$ MVIIC blocked only about $50 \%$ of the dihydropyridine-insensitive current in A-2 cells. The immunocytochemical detection of class $\mathrm{E}$ calcium channels in these cells suggests that at least a portion of the wCTX MVIICinsensitive or "R-type" $I_{\mathrm{Ca}}$ is carried via these channels. It is also possible that wCTX MVIIC block had not come to completion after $5 \mathrm{~min}$ with our recording conditions. It has been noted that $\omega$ CTX MVIIC block is slow in onset compared to other peptide blockers (Sather et al., 1993; Wheeler et al., 1994). Supporting the incomplete block hypothesis is the observation that block was greater $(58 \%, n=2)$ and WIN 55,212-2 $I_{\mathrm{Ca}^{-}}$ inhibition less $(4 \%, n=2)$ after $10 \mathrm{~min}$ of toxin exposure. This latter observation also suggests that cannabinoids modulate " $R$ type" $I_{\text {Ca }}$, weakly, if at all. Another explanation for incomplete block is that $\omega$ CTX MVIIC block is dependent on external divalent concentration, being prevented by $40 \mathrm{mM} \mathrm{Ba}^{2+}$ (Sather et al., 1993), and $5 \mathrm{~mm} \mathrm{Ca}^{2+}$ was used in the current study. In summary, as CB-1 receptors are highly concentrated at presynaptic endings in the CNS, including at some endings that have few N-type calcium channels (Herkenham et al., 1991; Matsuda et al., 1993), cannabinoid-mediated inhibition of Q-type $I_{\mathrm{Ca}}$ is a potential mechanism to decrcase neurotransmission and other calcium dependent processes at these synapses. Whether this is the basis for some or all of the psychoactive effects of the cannabinoids awaits further experimentation.

\section{References}

Adams ME, Myers RA, Imperial JS, Olivera BM (1993) Toxityping rat brain calcium channels with $w$-toxins from spider and conus snail venoms. Biochemistry 32:12566-12570.

Bean BP (1989) Neurotransmitter inhibition of neuronal calcium channels by changes in channel voltage dependence. Nature 340:153-156.

Birnbaumer L, Campbell KP, Catterall WA, Harpold MM, Hofmann F, Horne WA, Mori Y, Schwartz A, Snutch TP, Tanabe T, Tsien RW (1994) The naming of voltage-gated calcium channels. Neuron 13: 505-506.

Burgess TL, Kelly RB (1987) Constitutive and regulated secretion of proteins. Annu Rev Cell Biol 3:243-293.

Caulfield MP, Brown DA (1992) Cannabinoid receptor agonists inhibit Ca currents in NG108-15 neuroblastoma cells via a pertussis-toxin sensitive mechanism. Br J Pharmacol 106:231-232.

Chin H, Smith MA, Kim H-L, Kim H (1992) Expression of dihydropyridine-sensitive brain calcium channels in rat central nervous system. FEBS Lett 299:69-74.
Devane WA, Hanus L, Breuer A, Pertwee RG, Stevenson LA, Griffin G, Givson D, Mandelbaum A, Etinger A, Mechoulam R (1992) Isolation and structure of a brain constituent that binds to the cannabinoid receptor. Science 258:1946-1949.

Dousmanis AG, Pennefather PS (1992) Inwardly rectifying potassium conductances in AtT-20 clonal pituitary cells. Pfluegers Arch 422: 98-104.

Dubel SJ, Starr TVB, Hell J, Ahlijanian MK, Enyeart JJ, Catterall WA, Snutch TP (1992) Molecular cloning of the al subunit of an $\omega$-conotoxin-sensitive calcium channel. Proc Natl Acad Sci USA 89:50585062.

Felder CC, Briley EM, Axelrod J, Simpson JT, Mackie K, Devane W (1993) Anandamide, an endogenous cannabanoid, binds to the cloned human cannabinoid receptor and stimulates receptor mediated signal transduction. Proc Natl Acad Sci USA 90:7656-7660.

Forti L, Tottene A, Moretti A, Petrobon D (1994) Three novel types of voltage-dependent calcium channels in rat cerebellar neurons. $\mathbf{J}$ Neurosci 14:5243-5256.

Hagiwara S, Miyazaki S, Moody W, Patlak J (1978) Blocking effects of barium and hydrogen ions on the potassium current during anomalous rectification in the starfish egg. J Physiol (Lond) 279:167-185.

Hamill OP, Marty A, Neher E, Sakmann B, Sigworth FJ (1980) Improved patch-clamp techniques for high-resolution current recording from cell and cell-free membrane patches. Pfluegers Arch 391:85100.

Hell JW, Westenbroek RE, Warner C, Ahlijanian MK, Prystay W, Gilbert MM, Snutch TP, Cattcrall WA (1993) Identification and differential subcellular localization of the neuronal class C and class D L-type calcium channel $\alpha 1$ subunits. J Cell Biol 123:949-961.

Herkenham M, Lynn AB, Johnson MR, Melvin LS, de Costa BR, Rice KC (1991) Characterization and localization of cannabinoid receptors in rat brain: a quantitative in vitro autoradiographic study. J Neurosci 11:563-583.

Howlett AC (1985) Cannabinoid inhibition of adenylate cyclase: biochemistry of the response in neuroblastoma cell membranes. Mol Pharmacol 27:429-436.

Hoyer D, Boddeke HW (1993) Partial agonists, full agonists, antagonists: dilemmas of definition. Trends Pharamacol Sci 14:270-275.

Hui A, Ellinor PT, Krizanova O, Wang JJ, Diebodk RJ, Schwartz A (1991) Molecular cloning of multiple subtypes of a novel rat brain isoform of the $\alpha_{1}$ subunit of the voltage-dependent calcium channel. Neuron 7:35-44.

Ikeda S (1991) Double-pulse facilitation in adult rat sympathetic neurons. J Physiol (Lond) 439:181-214.

Jones SVP (1992) m4 muscarinic receptor subtype activates an inwardly rectifying potassium conductance in AtT20 cells. Neurosci Lett 147:125-130.

Kasai H (1992) Voltage- and time-dependent inhibition of neuronal calcium channels in a mammalian cell line. J Physiol (Lond) 448: 189-209.

Kubo Y, Reuveny E, Slesinger PA, Jan YN, Jan LY (1993) Primary structure and functional expression of a rat G-protein-coupled inuscarinic potassium channel. Nature 364:802-806.

Kuster JE, Stevenson JI, Ward SJ, D'Ambra TE, Haycock DA (1993) Aminoalkylindole binding in rat cerebellum: selective displacement by natural and synthetic cannabinoids. J Pharmacol Exp Ther 264: $1352-1363$.

Luini A, Lewis D, Guild S, Schofield G, Weight F (1986) Somatostatin, an inhibitor of ACTH secretion, decreases cytosolic free calcium and voltage-dependent calcium current in a pituitary cell line. J Neurosci $6: 3128-3132$.

Mackie K, Hille B (1992) Cannabinoids inhibit N-type calcium current in neuroblastoma-glioma cells. Proc Natl Acad Sci USA 89:38253829 .

Mackie K, Devane WA, Hille B (1993) Anandamide, an endogenous cannabinoid, inhibits $\mathrm{N}$-type calcium currents in N18 cells as a partial agonist. Mol Pharmacol 44:-503.

Marchetti C, Carbonne E, Lux HD (1986) Effects of dopamine and noradrenaline on $\mathrm{Ca} 2+$ channels of cultured sensory and sympathetic neurons of chick. Pfluegers Arch 406:104-111.

Matsuda LA, Lolait SJ, Brownstein MJ, Young AC, Bonner TI (1990) Structure of a cannabinoid receptor and functional expression of the cloned cDNA. Nature 346:561-564.

Matsuda LA, Bonner TI, Lolait SJ (1993) Localization of cannabinoid receptor mRNA in rat brain. $J$ Comp Neurol 327:535-550. 
Matsuuchi L, Kelly RB (1991) Constitutive and basal secretion from the endocrine cell line, AtT-20. J Ccll Biol 112:843-852.

Merrifield RB (1963) Solid phase peptide synthesis. I. The synthesis of a tetrapeptide. J Am Chem Soc 85:2149-2154.

Mintz IM, Bean BP (1993) GABA ${ }_{B}$ receptor inhibition of P-type $\mathrm{Ca}^{2+}$ channels in central neurons. Neuron 10:889-898.

Mori Y, Friedrich T, Kim M-S, Mikami A, Nakai J, Ruth P, Bosse E, Hofmann F, Flockerzi V, Furuichi T, Mikoshiba K, Imoto K, Tanabe T, Numa S (1991) Primary structure and functional expression from complementary DNA of a brain calcium channel. Nature 350:398402.

North RA (1989) Drug receptors and the inhibition of nerve cells. $\mathrm{Br}$ J Pharmacol 98:13-28.

Orth DN (1979) Adrenocorticotrophic hormone. In: Methods of hormone radioimmunoassay (Jaffe BM, Behrman HR, eds), pp 245-284. New York: Academic.

Pennefather PS, Heisler S, MacDonald JF (1988) A potassium conductance contributes to the action of somatostatin-14 to suppress ACTH secretion. Brain Res 444:436-450.

Pertwee RG (1993) Evidence for the existence of cannabinoid receptors. Gen Pharmacol 24:811-824.

Posnett DM, McGrath H, Tam JP (1988) A novel method for producing anti-peptide antibodies. Production of site-specific antibodies to the T cell antigen receptor beta-chain. J Biol Chem 263:1719-1725.

Randall A, Tsien RW (in press) Pharmacological dissection of multiple types of $\mathrm{Ca}^{2+}$ channel currents in rat cerebellar granule neurons. $\mathrm{J}$ Neurosci, in press.

Sather WA, Tanabe T, Zhang J-F, Mori Y, Adams ME, Tsien RW (1993) Distinctive biophysical and pharmacological properties of class A (BI) calcium channel $\alpha 1$ subunits. Neuron 11:291-303.

Seino S, Chen L, Seino M, Blondel O, Takeda J, Johnson JH, Bell G (1992) Cloning of the $\alpha 1$ subunit of voltage-dependent calcium channel expressed in pancreatic $\beta$ cells. Proc Natl Acad Sci USA 89:584588.

Snutch TP, Reiner PB (1992) Calcium ${ }^{2+}$ channels: diversity of form and function. Curr Opin Neurobiol 2:247-253.

Snutch TP, Leonard JP, Gilbert HA, Davidson N (1990) Rat brain expresses a heterogeneous family of calcium channels. Proc Natl Acad Sci USA 87:3391-3395.

Soong TW, Stea A, Hodson CD, Dubel SJ, Vincent SR, Snutch TP (1994) Structure and functional expression of a member of the lowvoltage-activated calcium channel family. Science 260:1133-1136.

Starr TVB, Prystay W, Snutch TP (1991) Primary structure of a cal- cium channel that is highly expressed in rat cerebellum. Proc Natl Acad Sci USA 88:5621-5625.

Surprenant A, Horstman DA, Akbarali H, Limbird LE (1992) A point mutation on the $\alpha_{2}$-adrenoreceptor that blocks coupling to potassium but not calcium channcls. Scicnce 257:977-980.

Swartz KJ (1993) Modulation of $\mathrm{Ca}^{2+}$ channels by protein kinase $\mathrm{C}$ in rat central and peripheral neurons: disruption of $\mathrm{G}$ protein-mediated inhibition. Neuron 11:305-320.

Takahashi T, Momiyama A (1993) Different types of calcium channels mediate central synaptic transmission. Nature 366:156-158.

Thermos K, Reisine T (1988) Somatostatin receptor subtypes in the clonal anterior pituitary cells lines AtT-20 and $\mathrm{GH}_{3}$. Mol Pharmacol 33:370-377

Tomlinson WJ, Stea A, Bourinet E, Charnet P, Nargeot J, Snutch TP (1993) Functional properties of a neuronal class C L-type calcium channel. Neuropharmacology 32:1117-1126.

Tooze J, Hollinshead M, Fuller SD, Tooze SA, Huttner WC (1989) Morphological and biochemical evidence showing neuronal properties of AtT-20 cells and their growth cones. Eur J Cell Biol 49:259 273.

Turner TJ, Adams ME, Dunlap K (1993) Multiple $\mathrm{Ca}^{2+}$ channel types coexist to regulate synaptosomal neurotransmitter release. Proc Natl Acad Sci USA 90:9518-9522.

Westenbroek RE, Hell JW, Warner C, Dubel SJ, Snutch TP, Catterall WA (1992) Biochemical properties and subcellular distribution of a N-type calcium channel alpha 1 subunit. Neuron 9:1099-1115.

Westenbroek RE, Sakurai T, Elliott EM, Hell JW, Starr TVB, Snutch TP, Catterall WA (1995) Immunocytochemical identification and subcellular distribution of the $\alpha_{1 \mathrm{~A}}$ subunits of brain calcium channels. J Neurosci 15:6403-6418

Wheeler DB, Randall A, Tsien RW (1994) Roles of N-type and Q-type $\mathrm{Ca}^{2+}$ channels in supporting hippocampal synaptic transmission. Science 264:107-111.

Williams HE, Feldman DH, McCue AF, Brenner R, Velicelebi G, Ellis SB, Harpold MM (1992) Structure and functional expression of $\alpha_{1}$, $\alpha_{2}$ and $\beta$ subunits of a novel neuronal calcium channel subtype. Neuron 8:71-84.

Yokoyama CT, Westenbroek RE, Hell JW, Soong TW, Snutch TP, Catterall WA (1995) Biochemical properties and subcellular distribution of the neuronal class $E$ calcium channel $\alpha_{1}$ subunit. J Neurosci 15 : 6419-6432.

Zhang J-F, Randall AD, Ellinor PT, Horne WA, Sather WA, Tanabe T, Schwarz TL, Tsien RW (1993) Distinctive pharmacology and kinetics of cloned neuronal calcium channels and their possible counterparts in mammalian CNS neurons. Neuropharmacology 32:10751088 . 